\title{
The Effects of Grape Seed Extract on Insulin, Adiponectin and Resistin Levels in Diabetic Rats
}

\author{
İnci Söğ̈̈tlï̈ ${ }^{1, a, *}$, Nihat Mert ${ }^{2, b}$, Handan Mert ${ }^{2, c}$, Leyla Mis ${ }^{3, d}$, Halil Cumhur Yılmaz ${ }^{4, e}, K_{\text {Kivanç İrak }}^{5, f}$ \\ ${ }^{1}$ Ministry of Agriculture and Forestry, 06800 Ankara, Turkey \\ ${ }^{2}$ Department Biochemistry, Faculty of Veterinary Medicine, Van YYU, 65080 Van, Turkey \\ ${ }^{3}$ Department Physiology, Faculty of Veterinary Medicine, Van YYU, 65080 Van, Turkey \\ ${ }^{4}$ Department Histology and Embryology, Faculty of Veterinary Medicine, Van YYU, 65080 Van, Turkey \\ ${ }^{5}$ Department Biochemistry, Faculty of Veterinary Medicine, Siirt University, 56000 Siirt, Turkey \\ *Corresponding author
}

\begin{tabular}{l|l}
\hline A R T I C L E I N F O & A B S T R A C T \\
\hline $\begin{array}{l}\text { Research Article } \\
\text { Received : 24/10/2020 } \\
\text { Accepted : 21/02/2021 }\end{array}$ & $\begin{array}{l}\text { In this study, the effects of grape seed extract on insulin, adiponectin and resistin levels in diabetic } \\
\text { rats were aimed to investigate. Weight of about 300-350g 7-8 weeks 32 female Wistar Albino rats } \\
\text { were used. Weight of about 300-350g 7-8 weeks 32 female Wistar Albino rats randomly divided } \\
\text { into four groups of eight each: control group (C), group with diabetes (DM), grape seed extract } \\
\text { group (GSE), diabetes mellitus and grape seed extract group (DM+GSE). The diabetic group 45 } \\
\text { mg/kg single dose of streptozotocin was administered intraperitoneally, and the grape seed extract } \\
\text { groups (DM+GSE and GSE) grape seed extract was given orally every day with an intragastric tube } \\
\text { for } 20 \text { days (0.6 ml/rat). Blood samples were taken from the hearts of rat's end of the experiment. } \\
\text { The sera obtained were used for insulin, adiponectin and resistin analysis measured via ELISA with } \\
\text { commercial kits. The insulin and adiponectin levels of the rats in the diabetes + grape seed extract } \\
\text { group were found to be higher than those in the diabetes group. There was no significant change in } \\
\text { the resistin level differences between the groups. As a result; It is possible to say that grape seed } \\
\text { extract has an increasing effect on insulin level and adiponectin levels of diabetic rats are decreased } \\
\text { due to diabetes and it has no significant effect on resistin levels. Detected by the positive effects of } \\
\text { grape seed extracts, it may be useful to use for the regulating of the diabetes in human. }\end{array}$ \\
$\begin{array}{l}\text { Keywords: } \\
\text { Diabetes Mellitus }\end{array}$ \\
$\begin{array}{l}\text { Adipulin } \\
\text { Resistin } \\
\text { Rat }\end{array}$
\end{tabular}

\section{Introduction}

Diabetes mellitus; It is a metabolic disease characterized by insulin secretion deficiency and resistance to the metabolic effect of insulin in target tissues Diabetes is recognised as one of the leading causes of morbidity and mortality in the world. (Walter et al., 1991; Seghrouchni et al., 2002). Glucose metabolism is impaired as a result of the disease. This condition causes an increase in blood sugar levels and severe damage, especially to blood vessels and nerves (Phillips et al., 2004).

Plants have long been the main source of medicines, and many of today's medicines are obtained directly or indirectly from plants. Many active substances derived from different chemical compound groups of plant origin and their commercial preparations can be used in the treatment and studies of diabetes. Nowadays, it has been observed that alternative treatments are needed to control diabetes and reduce its complications. Many medicinal plants with antioxidant effects are used in the treatment and prevention of diabetes.

Many active substances and their commercial preparations derived from plant-derived groups of different chemical compounds can be used in the treatment of diabetes. Traditional medicinal plants having antioxidant activity can be done by antioxidant vitamins, phenols or tannins. Phenols, especially flavonoids, have been shown to exhibit antioxidant activity (Rice-Evans, 1995; Cao et al., 1997) 
Catechin, epicatechin, quercetin, phenolic acids (pkumaric, cinnamic, caffeic, genticidal, ferulic and vanilic acid), trihydroxy stilbenes (resveratrol and polydatin) were dedected in grape seed extract (Takahashi and Koboyashi, 2003).

Oligomeric and polymeric flavan-3-ol units, which are composed of epicatechin and their galaxies, are called proanthocyanins (Plumb et al., 1998). Proanthocyanidins provide inhibition of free oxygen radicals depending on concentration. Among the various medicinal and therapeutic pharmacological effects of proanthocyanidins to date are vasodilatory, anti-carcinogenic, anti-allergic, anti-inflammatory, antifungal, anti-arthritic, antibacterial, cardioprotective, immunostimulating and antiviral effects (Özel, 2006).

Insulin is a peptide hormone secreted by Langerhans' pancreatic islets $\beta$ cells and promotes cell division by facilitating cellular glucose uptake, regulating carbohydrate, lipid and protein metabolism, and through its mitogenic effects and maintain normal blood glucose levels by promoting growth. Insulin secretion is characteristically biphasic in response to a stimulus such as glucose, initially a rapid phase of insulin secretion followed by a less intense but longer lasting hormone release occurs (Wilcox, 2005). The insulin concentration in blood is approximately $1 \mathrm{ng} / \mathrm{ml}$, and the predominant form is monomeric. However, the insulin molecule combines with hexamers at higher insulin concentrations, and this property is supported by acid or neutral $\mathrm{pH}$ and $\mathrm{Zn}^{+2}$. In insulin-secreting granules in cells-cells, with two $\mathrm{Zn}^{+2}$ ions per hexamer stored as coordinated hexamers (Petrusa et al., 2017).

Adiponectin is thought to play an important role in the modulation of glucose and lipid metabolism in insulinsensitive tissues in both humans and animals. Decreased circulating adiponectin levels have been demonstrated in genetic and diet-induced mouse obesity models of obesity (Yamauchi et al., 2001) as well as dietary forms of human 23 obesity. Low adiponectin levels have also been strongly implicated in the development of insulin resistance in both obesity and lipoatrophy mouse models (Chandran ve Phillips, 2003).

It has been termed resistin ("insulin resistance") and was first identified in mice, also in humans (Berger, 2001). The term "resistin" has been applied to a family of proteins commonly known as "resistin-like molecules" (RELM). Proteins RELM- $\alpha$ and RELM- $\beta$ also belong to the family. Resistin is a polypeptide containing 114 amino acid residues and secreted as a disulfide-conjugated dimer. Resistin is known to be produced in adipose tissue in mice. There is an assumption that the level of resistin may be a triggering factor of metabolic disorders associated with diabetes and obesity in mice (Urbanovych, 2015). Resistin in human preadipocytes is an in vitro insulin antagonist. Human liver cells overexpressing resistin have impaired glucose uptake and glycogen synthesis. Recent studies show that resistin are pro-inflammatory cytokines. With pathophysiological conditions such as atherosclerosis, kidney disease, respiratory tract inflammation and type 2 diabetes mellitus. It has been shown to be positively correlated with proinflammatory factors in adults (Jinhua, 2012).
In this study, it was aimed to investigate the effect of grape seed extract on diabetes created with STZ, and also the changes in insulin, adiponectin and resistin levels.

\section{Material and Methods}

The animal material of the work was obtained from the Center of Y.Y. University Experimental Animal Unit. Thirty-two female Wistar Albino rats, approximately 7-8 weeks old, were used in the study. The subjects were randomly selected and divided into 4 groups. The study was conducted with the decision of the Board of Ethics Committee of Yüzüncü Y1l University Animal Experiments on 05.09.2013 and numbered 2013-09.

The groups were formed as follows;

- Control group (C): Pre-test blood sugar levels of animals with female rats weighing were measured. Intraperitoneal (i.p.) injection of $45 \mathrm{mg} / \mathrm{kg}$ single dose of saline was performed.

- Group with diabetes (DM): Pre-experiment blood sugar levels of animals were measured. To induce diabetes in rats, is administered in a single injection in doses of $45 \mathrm{mg} / \mathrm{kg}$. STZ dissolved in cold citrate buffer at $\mathrm{pH}$ 4.5: STZ (Sigma, USA) and administered intraperitoneally (i.p.) (Karabay et al., 2006). After 72 hours, glucose levels in the blood samples taken from the tail vein were determined by means of Levers Chek-TD-4222 biosensor sugar meter and strips. Rats with blood glucose levels above $250 \mathrm{mg} / \mathrm{dl}$ were considered diabetic and included in the study.

- $\quad$ Grape seed extract group (GSE): Grape Seed Extract 100 mg-SOLGAR was kept in CMC (carboxy methyl cellulose) $(0.01 \mathrm{~g} / \mathrm{ml})$, vortexed and intragastically given every day for 20 days. $(0.6 \mathrm{ml} /$ rat $)$ (Chis et al., 2009).

- Diabetes mellitus and grape seed extract group (DM+GSE): Grape seed extract (100 mg-SOLGAR) in CMC (carboxymethyl cellulose) $(0.01 \mathrm{~g} / \mathrm{ml})$ administered intragastically via the mouth every day for 20 days $(0.6 \mathrm{ml} / \mathrm{rat})$ to the rats diagnozed as DM same in group 2 which their blood glucose above 250 mg / dl (Chis et al., 2009). At the end of the trial i.p. blood samples were taken from the hearts of rats under anaesthesia, centrifuged at $3000 \mathrm{rpm}$ for 10 minutes. Sera were separated and stored at $-18^{\circ} \mathrm{C}$ in deep freezing until the assay was done. The obtained serum was analysed for insulin, adiponectin and resistin (The Mouse adiponectin ELISA Kit YL Biont (Art No: YLA0076RA), The Mouse Resistin ELISA Kit YL Biont (Art No: YLA0203RA), The Mouse Insulin ELISA Kit YL Biont (Art No: YLA0037RA).

\section{Statistical Analysis}

Statistical package program was used for statistical analysis to evaluate the data obtained. In the comparison of quantitative data, Kruskal-Wallis test was used for the comparison of the groups with no normal distribution, and Mann-Whitney U test was used for the group that caused the difference. The results were assessed at $95 \%$ confidence interval, $\mathrm{P}<0.05, \mathrm{P}<0.01$ and $\mathrm{P}<0.001$ significance level, respectively. 
Table 1. Insulin, adiponectin and resistin levels of rats in control, diabetes, grape seed extract and diabetes + grape seed extract group

\begin{tabular}{l|cccccc}
\hline \multicolumn{1}{c|}{ Parameters } & $\mathrm{N}$ & Control & GSE & Diabetes & Diabetes+GSE & P \\
\hline Insulin $(\mu \mathrm{g} / \mathrm{l})$ & 8 & $3.21 \pm 0.10^{\mathrm{a}}$ & $3.08 \pm 0.13^{\mathrm{a}}$ & $1.72 \pm 0.06^{\mathrm{c}}$ & $2.86 \pm 0.09^{\mathrm{b}}$ & 0.01 \\
Adiponectin $(\mu \mathrm{g} / \mathrm{l})$ & 8 & $7.25 \pm 1.20^{\mathrm{a}}$ & $8.01 \pm 1.17^{\mathrm{a}}$ & $4.56 \pm 0.98^{\mathrm{c}}$ & $6.38 \pm 1.04^{\mathrm{b}}$ & 0.003 \\
Resistin $(\mathrm{pg} / \mathrm{ml})$ & 8 & $0.44 \pm 0.03^{\mathrm{a}}$ & $0.41 \pm 0.06^{\mathrm{a}}$ & $0.36 \pm 0.04^{\mathrm{a}}$ & $0.40 \pm 0.04^{\mathrm{a}}$ & 0.392 \\
\hline
\end{tabular}

a, b, c: Different letters in the same row are statistically significant

\section{Results}

The levels of data obtained from female Wistar Albino rats are presented in Table 1. At the end of the study, the difference between the groups' insulin mean levels was found to be significant $(\mathrm{P}<0.01)$. Insulin levels significantly decreased in diabetes group. Addition of GSE to rats' diet, insulin levels increased close to the control values. Similarly, the adiponectin levels of rats in different groups were also significant $(\mathrm{P}<0.003)$. The lowest level was determined in diabetes group and increased in Diabetes+GSE group. The resisitin levels were not significantly changed the lowest level was found in diabetes group $(\mathrm{P} \geq 0.05)$. (Table 1$)$.

\section{Discussion}

Diabetes Mellitus (DM) is an endocrine and metabolic disease characterized by impaired carbohydrate, lipid and protein metabolism, caused by insulin dependence or insulin resistance. During the illness, specific complications such as retinopathy, nephropathy, neuropathy, atherosclerosis develop and many people lose their lives because of these complications (Irak et al., 2018a).

Grape and grape products contain flavonoids such as monomeric flavonol, dimeric, trimeric and polymeric proanthocyanidins and phenolic acids such as gallic and epigallic acid. Proanthocyanidins known as condensed tannins are found mostly in the crust and in the core part of the grape (Kaya, 2008; Souquet et al., 1996). Tannins are hydroxylated, functioning by forming insoluble complexes with carbohydrates and proteins and protecting connective tissue (Jimenez-Ramsey et al., 1994)

Resveratrol, which is found intensely in the seed of grapes, shell and stalk, is an important bioactive substance that plays antioxidant, antimicrobial, anticarcinogenic and antimutagenic roles in the protection against cardiological diseases, inhibition of oxidation of LDL cholesterol, inhibition of free radicals (Sagdic and Ekici, 2005). Proanthocyanidins have an antioxidative effect 20 and 50 times stronger than vitamins $\mathrm{E}$ and $\mathrm{C}$, respectively (Shi et al., 2003).

Clinical trials evaluating the effect of the grape seed extract in diabetic people have shown that the $600 \mathrm{mg}$ grape seed extract daily affects glucose metabolism positively and reduces oxidative stress in Type 2 diabetics. It has been reported that resveratrol in grape seed and shell has a role in protecting from diabetes and alleviating some diabetic complications. It has been suggested that resveratrol in diabetic rats partially alleviates plasma glucose and triglyceride concentrations, improves metabolic parameters, and reduces insulinemia (Atten et al., 2001; Kim et al., 2001; Leiro et al., 2002). In a study of single-dose $(60 \mathrm{mg} / \mathrm{kg}$ ) intravenous streptozotocin injections in rats with diabetes mellitus, resveratrol was reported to have a dose-dependent reduction in plasma glucose and lipid concentrations and to improve general symptoms of diabetes mellitus (Su et al., 2006).

In this presented study, as seen in Table 1, while insulin level decreased significantly in rats with diabetes compared to the control group, a significant increase was found when GSE was given to the diabetic group ( $p<0.01$ ). Some researchers reported that this hypoglycemic effect of GSE is moderate, it is caused by the ingestion of glucose and the increase of glycogen synthesis. It has been reported that epicatechin in grape seeds induces hypoglycemia by stimulating the regeneration of beta cells, catechins reducing intestinal glucose absorption and epigallocatechines increasing hepatic glycogen synthesis (Siemann and Creasy, 1992)

In studies examining the effect of adiponectin on cardiovascular diseases, it has been reported that its protective effect against arteriosclerosis was found. The relationship between this pathology and the low amount of adiponectin has been revealed. It also causes cardiovascular diseases such as obesity and type II diabetes mellitus in male subjects with hypertension. A link with some risk factors in pathologies has also been identified (Arita et al., 1999; Ouchi et al., 2000).

Adiponectin is believed to regulate the nuclear factor $\mathrm{kB}$ signal via the cAMP-dependent gate. Therefore, it is thought that endothelial cells act as an endogenous regulator in response to inflammatory stimuli (Ouchi et al., 2000). In the light of all these data, this cytokinin, which is an adipocyte derivative, is anti-inflammatory and antiatherogenic especially in macrophages and endothelial cells. The presence of effects can be considered. In addition, it can be said that this substance plays a protective role in the events that take place at the beginning of atherosclerosis in the models of vascular damage. Recent observations point to a potential role for adiponectin in a variety of injurious diseases. Serum adiponectin levels have been found to be associated with systemic lupuserythematosus, cystic fibrosis, inflammatory bowel disease, and rheumatoid arthritis (Otero et al., 2006; Karmiris et al., 2006). The significance of these findings is not yet understood. Whether high adiponectin is a part of the observed inflammatory response or the relationship between low adiponectin content (or those that may increase adiponectin less) and a more susceptibility to inflammation should be further elucidated. Significant associations have been identified between improvement in insulin sensitivity and adiponectin levels.

Similar to the amount of insulin, as seen in Table 1, adiponectin level decreased significantly in rats with diabetes compared to the control group, while a significant increase was found when GSE was given to the diabetic group. 
When the resistin was first identified in 2001 (Steppan et al., 2001), several important discoveries were reported: plasma resistin levels were increased in diet-induced and genetic forms of the obese mouse model; administration of an anti-resistin antibody increased insulin sensitivity in obese and insulin resistant animals; treatment of healthy mice with recombinant resist with impaired glucose tolerance and insulin action; and administration of resistin impaired insulin-induced glucose uptake in adipocytes. From these observations, it is suggested that resistine plays an important role in insulin resistance and obesity in the diabetic mouse model. It has also been difficult to determine the usability of the obtained findings in human studies. Regarding their secretion, resistin is secreted from white adipose tissue in mice, whereas in humans it is synthesized from circulating blood monocytes and in lower amounts in white adipose tissue (Savage et al., 2001). Several studies support a positive correlation between elevated serum resistin level in humans and obesity, insulin resistance, and so on. First, it has been described that the resist is expressed in human hepatocytes and induces insulin resistance (Sheng et al., 2008). Findings of the relationship between resistin and obesity and / or diabetes. There are reports of inconsistencies. In some rodent models, it has been shown that resistin mRNA expression in adipose tissue of obese animals does not correlate with serum resistin levels that do not correlate with serum insulin or glucose. It was reported that both increased and did not change (Lee et al., 2003).

The effect of GSE on resistin is also shown in Table 1, and a similar level was found in the four groups studied, and the level differences between the groups did not show statistical significance. Although the rats with diabetes seemed to have decreased resistin, the addition of GSE caused the decreased amount to increase.

As a result, GSE has a positive effect on insulin and adiponectin level changes in diabetic rats, preventing possible diabetes complications, and as shown in previous our studies (Irak et al., 2018b), it can be used for the treatment of diabetic individuals with its restorative effects on the pancreatic structure.

\section{References}

Arita Y, Kihara S, Ouchi N, Takahashi M, Maeda K, Miyagawa J, Hotta K, Shimomura I, Nakamura T, Miyaoka K, Kuriyama H, Nishida M, Yamashita S, Okubo K, Matsubara K, Muraguchi M, Ohmoto Y, Funahashi T, Matsuzawa Y. 1999. Paradoxical decrease of an adipocyte specific protein, adiponectin in obesity. Biochem Biophys Res Commun, 257: 79-83. doi: 10.1006/bbrc.1999.0255.

Atten MJ, Atar BM, Milson T, Holian O. 2001. Resveratrolinduced inactivation of human gastric adenocarcinoma cells through a protein kinase C-mediated mechanism, Biochemical Pharmacology, 6(2): 1423-1432. doi: 10.1016/ s0006-2952 (01) 00788-2.

Berger A. 2001. Resistin: A new hormone that links obesity with type 2 diabetes. BMJ, 322(7280): 193.

Cao G, Sofic E, Prior RL. 1997. Antioxidant and prooxidant behavior of flavonoids: structure activity relationships. Free Radical Biology and Medicine, 22:749-760. doi: 10.1016/s0891-5849(96)00351-6

Chandran M, Phillips S. 2003. Adiponectin: More than just another fat cell hormone? Diabetes Care, 26: 2442-50. doi: 10.2337/diacare.26.8.2442.
Chis IC, Ungureanu MI, Marton A, Simedrea R, Muresan A, Postescu ID, Decea N. 2009. Antioxidant effects of a grape seed extract in a rat model of diabetes mellitus. Diab Vasc Dis Res, 6 (3): 200-204. doi: 10.1177/1479164109336692.

Irak K, Mert N, Mert H, Ayşin, N. 2018a. The Effects of Grape Seed Extract on The Some Enzymes and Metabolites in Diabetic Rats. Van Veterinary Journal, 29(3): 147-152.

Irak K, Yıldırım S, Mert H, Mert N. 2018b. Grape seed extract effects on serum amylase levels and immunohistochemical alterations in Streptozotocin-induced diabetic rats. Cellular and Molecular Biology, 64 (4): 92-97. doi: $10.14715 / \mathrm{cmb} / 2018.64 .4 .15$

Jimenez-Ramsey LM, Rogler JC, Housley TL, Butler LG, Eklin RG. 1994. Absorption and distribution of ${ }^{14} \mathrm{C}$-labeled condensed tannins and related sorghum phenolics in chickens. J Agric Food Chem, 42: 963-967. doi: 10.1021/jf00040a024

Jinhua Y, Hongfei G, Jing Y, Lu X, Ming L. 2012. Measurement of salivary resistin level in patients with type 2 diabetes. Int $\mathbf{J}$ Endoc. Article ID 359724: 5. doi: 10.1155/2012/359724

Karabay G, Zağyapan R, Take G. 2006. Streptozotosinle oluşturulan diabetin sıçan periferik sinirleri üzerine etkisinin elektron mikroskobik incelenmesi. Uludağ Üniv Tıp Fak Derg, 32(3): 77-81.

Karmiris K, Koutroubakis IE, Xidakis C, Polychronaki M, Voudouri T, Kouroumalis EA. 2006. Circulating levels of leptin, adiponectin, resistin, and ghrelin in inflammatory bowel disease. Inflamm Bowel Dis, 12: 100-5. doi: 10.1097/01.MIB.0000200345.38837.46.

Kaya S. 2008. Beşerî Hekimlikte Kullanılan Tıbbi Bitkiler: Üzüm. Tıbbi Botanik ve Tibbi Bitkiler. Medisan Yayınevi, 239, Ankara

Kim JK, Kim YJ, Fillmore JJ, Chen Y, Moore I, Lee J, Yuan M, Li ZW, Karin M, Perret P, Shoelson SE, Shulman G. 2001. Prevention of fat-induced insulin resistance bysalicylate, J Clin Invest, 108 (3): 437-446 doi: 10.1172/JCI1 1559

Lee JH, Chan JL, Yiannakouris N, Kontogianni M, Estrada E, Seip R, Orlova C, Mantzoros CS. 2003. Circulating resistin levels are not associated with obesity or insulin resistance in humans and are not regulated by fasting or leptin administration: cross-sectional and interventional studies in normal, insulin-resistant, and diabetic subjects. J Clin Endocrinol Metab, 88: 4848- 56 doi: 10.1210/jc.2003-030519

Leiro J, Alvarez E, Garcia D, Orallo F. 2002. Resveratrol modulates rat macrophage functions, Int Immunopharmacol, 2: 767-774. doi: 10.1016/S1567-5769(02)00014-0

Otero M, Lago R, Gomez R, Lago F, Dieguez C, Gomez-Reino JJ, Gualillo O. 2006. Changes in plasma levels of fat-derived hormones adiponectin, leptin, resistin and visfatin in patients with rheumatoid arthritis. Ann Rheum Dis, 65: 1198-201. doi: 10.1136/ard.2005.046540

Ouchi N, Kihara S, Arita Y, Okamoto Macda K, Kuriyama H, Hotta K, Nishida M, Takahashi M, Muraguchi M, Ohmoto Y, Nakamura T, Yamashita S, Funahashi T, Matsuzava Y. 2000. Adiponectin, adipocyte-derived plasma protein inhibits endothelial NFKB signaling through cAMP dependent pathway. Circulation, 102: 1296-301.

Özel Y. 2006. Ratlarda karaciğer iskemi/reperfüzyon hasarında grape seed proanthocyanidinin koruyucu etkilerinin incelenmesi, Uzmanlık Tezi, Sağlık Bakanlığı, Haydarpaşa Numune Eğitim ve Araştırma Hastanesi, 5. Genel Cerrahi Kliniği, İstanbul.

Pertusa JA, León-Quinto T, Berná G, Tejedo JR, Hmadcha A, Bedoya, FJ, Soria B. 2017. Zn2+ chelation by serum albumin improves hexameric $\mathrm{Zn} 2+-$ insulin dissociation into monomers after exocytosis. PLoS One, 12(11): e0187547.

Phillips M, Cataneo R, Cheema T, Greenberg J. 2004. Increased breath biomarkers of oxidative stress in diabetes mellitus. Clin Chim Acta, 344(1-2): 189-94.doi: 10.1016/j.ccen.2004.02.025 
Plumb GW, Pascual-Teresa SD, Santos-Buelga C, Cheynier V, Williamson G. 1998. Antioxidant properties of catechins and proanthocyanidins: Effect of polymerisation, galloylation and glycosylation. Free Radic Res, 29(4):351-358. doi: 10.1080/10715769800300391.

Rice-Evans C. 1995. Plant polyphenols free radical scavengers or chain-breaking antioxidants. Biochem Soc Symp, 61:103-16

Sagdic O, Ekici L. 2005. Phenolic compounds and bioactivities of grape (Vitis vinifera) and its seed. Journal of Hasad Food, 21 (244): 30-34.

Savage DB, Sewter CP, Klenk ES, Segal DG, Vidal-Puig A, Considine RV, O'Rahilly S. 2001. Resistin/Fizz3 expression in relation to obesity and peroxisome proliferator-activated receptor-gamma action in humans. Diabetes, 50: 2199-202. doi: $10.2337 /$ diabetes.50.10.2199

Seeram N, Aviram M, Zhang Y, Henning S. 2008. Comparison of antioxidant potency of commonly consumed polyphenolrich beverages in the United States. J Agric Food Chem, 56(4):1415-22. doi: 10.1021/jf073035s

Seghrouchni I, Drai J, Bannier E, Riviere J, Calmard P, Garcia I, Orgiazzi J, Revol A. 2002. Oxidative stress parameters in type I, type il and insulin-treated type 2 diabetes mellitus, Insulin treatment efficiency. Clin chim acta, 321 (1-2): 89-96. doi: 10.1016/s0009-8981(02)00099-2

Sheng CH, Di J, Jin Y, Zhang YC, Wu M, Sun Y, Zhang GZ. 2008. Resistin is expressed in human hepatocytes and induces insulin resistance. Endocrine, 33: 135-43. doi: 10.1007 / s12020-008-9065-y

Shi J, Yu J, Pohorly JE, Kakuda Y. 2003. Polyphenolics in grape seeds-biochemistry and functionality. J Med Food, 6 (4): 291 299 doi: 10.1089/109662003772519831

Siemann EH, Creasy LL. 1992. Concentration of the phytoalexin resveratrol in wine. Am J Enol Vitic, 43: 49-52.
Souquet JM, Cheynier V, Brossaud F, Moutounet M. 1996. Polymeric proanthocyanidins from grape skins, Phytochemistry, 43(2): 509-512. doi: 10.1016/0031-9422(96) 00301-9

Steppan CM, Brown EJ, Wright CM, Bhat S, Banerjee RR, Dai CY, Enders GH, Silberg DG, Wen X, Wu GD, Lazar MA. 2001. A family of tissue-specific resistin-like molecules. Proc Natl Acad Sci USA, 98: 502-6. doi: 10.1073/pnas.98.2.502

Su HC, Hung LM, Chen JK. 2006. Resveratrol, a red wine antioxidant, possesses an insulin-like effect in streptozotocininduced diabetic rats. Am J Physiol Endocrinol Metab, 290: 1339-1346. doi: 10.1152/ajpendo.00487.2005

Takahashi T, Koboyashi A. 2003. Proanthocyanidin-containing composition, United Patent Office, 6: 506, 419.

Urbanovych A. 2015. The blood resistin level in patients with DM2, depending on the duration of the disease. Curr Issues Pharm Med Sci, 28(2):111-4. doi: 10.1515/cipms-2015-0055

Walter R, Uriu-Hare J, Olin K, Oster M, Anawalt B. 1991. Copper, zinc, manganese, and magnesium status and complications of diabetes mellitus. Diabet Care, 14:1050-6. doi: $10.2337 /$ diacare.14.11.1050

Wilcox G. 2005. Insulin and Insulin Resistance. Clin Biochem Rev, 26(2):19-39.

Yamauchi T, Kamon J, Waki H, Terauchi Y, Kubota N, Hara K, Mori Y, Ide T, Murakami K, Tsuboyama-Kasaoka N, Ezaki O, Akanuma Y, Gavrilova O, Vinson C, Reitman ML, Kagechika H, Shudo K, Yoda M, Nakano Y, Tobe K, Nagai R, Kimura S, Tomita M, Froguel P, Kadowaki T. 2001. The fat derived hormone adiponectin reverses insulin resistance associated with both lipoatrophy and obesity. Nat Med,7: 941-6. doi: 10.1038/90984 